\title{
Rhodococcus marinonascens sp. nov., an Actinomycete from the Sea
}

\author{
ELISABETH HELMKE AND HORST WEYLAND* \\ Institut für Meeresforschung Bremerhaven, D-2850 Bremerhaven, Federal Republic of Germany
}

\begin{abstract}
Two groups of nocardioform organisms isolated from marine sediments were studied, along with representative strains of the genera Rhodococcus, Nocardia, and Mycobacterium. Strains of the red- or orange-colored group showed no marine affinity and exhibited a close relationship to Rhodococcus rhodochrous. The 17 marine isolates of the cream-colored group formed a homogeneous well-separated cluster and were particularly characterized as moderately halophilic and psychrotrophic organisms. These isolates were assigned to a new species within the genus Rhodococcus: We propose the name Rhodococcus marinonascens, referring to the exclusive occurrence of this taxon in the sea, and describe the properties of the species and of type strain $3438 \mathrm{~W}$ (= DSM 43752).
\end{abstract}

In the bottom sediments of various open sea sites in the northeastern Atlantic Ocean (North Atlantic Ridge, Iberian Sea, Bay of Biscay, North Sea, off the Faeroe Islands, Norwegian Sea, and Barents Sea), nocardioform bacteria have been detected $(34,35)$. The marine nocardioform isolates can be divided into two groups on the basis of pigmentation type. The majority of the isolates are cream colored, moderately halophilic, and psychrotrophic, whereas the other isolates are red or orange and obviously not adapted to the conditions of the marine environment. Preliminary morphological and physiological studies have shown clear differences between the red or orange organisms and the cream-colored organisms, but within a color group the strains are almost identical. To define the taxonomic status of the marine strains, we used chemotaxonomic and numerical methods. The marine nocardioform isolates were compared with representatives of the genera Mycobacterium, Nocardia, and Rhodococcus and with strains of organisms not included on the Approved Lists of Bacterial Names (30). The marker strains were selected partially on the basis of previous chemotaxonomic studies which indicated some relationship to the marine organisms.

\section{MATERIALS AND METHODS}

Organisms. The strains included in this taxonomic study are listed in Table 1. The reference strains were received from the Deutsche Sammlung für Mikroorganismen, Göttingen, Federal Republic of Germany. The marine strains were isolated from the uppermost layer of marine sediments from various sea sites by using methods and media previously described $(35,36)$.

Test conditions. For purposes of comparison, the cultural and physiological tests were carried out with all strains under the same conditions. Unless stated otherwise, we used an incubation temperature of $18^{\circ} \mathrm{C}$ and test media containing $75 \%$ seawater or an equivalent salt content. The cultures used for inoculation of test media were grown in liquid yeast extract-malt extract medium (36) for 8 days and then centrifuged, washed with tap water, suspended in liquid BMS medium (see below), and homogenized for $5 \mathrm{~s}$ by using a high-speed blender (Ultraturrax; IKA Werk, Staufen, Federal Republic of Germany).

\footnotetext{
* Corresponding author.
}

The growth and utilization tests were performed in polystyrene replidishes that were divided into 25 separate compartments (Greiner, Nürtlingen, Federal Republic of Germany). The dishes were inoculated with a multipoint inoculator (Greiner). Degradation of different substrates and susceptibility to antibiotics were studied in plastic petri dishes.

Nitrate reduction, resistance to lysozyme, and urease activity were examined in test tubes.

Physiological tests. The production of acid from different carbohydrates was detected in BMS-N medium, which contained $1.0 \mathrm{~g}$ of $\left(\mathrm{NH}_{4}\right)_{2} \mathrm{HPO}_{4}, 0.2 \mathrm{~g}$ of $\mathrm{KCl}, 0.2 \mathrm{~g}$ of $\mathrm{MgSO}_{4} \cdot 7 \mathrm{H}_{2} \mathrm{O}, 25.0 \mathrm{~g}$ of $\mathrm{NaCl}, 15.0 \mathrm{~g}$ of agar no. 1 (Oxoid Ltd., London, England), 1,000 $\mathrm{ml}$ of distilled water, and 15 $\mathrm{ml}$ of a $0.04 \%$ (wt/vol) aqueous bromocresol purple solution. The $\mathrm{pH}$ of this medium was adjusted to 7.0 with $1 \mathrm{~N} \mathrm{HCl}$. After autoclaving, the carbohydrate to be tested (final concentration, $1 \% \mathrm{wt} / \mathrm{vol}$ ) and yeast nitrogen base without amino acids (final concentration, $0.067 \%$, wt $/ \mathrm{vol}$; Difco Laboratories, Detroit, Mich.) were added aseptically. Most of the carbohydrates were sterilized by filtration. Inulin, dextrin, and salicin were autoclaved separately, and dulcitol was sterilized by steaming for $30 \mathrm{~min}$ on 3 consecutive days. The inoculated media were scored for changes in color (indicating acid production) every week for 5 weeks. The last reading was taken after 2 months.

The tests for utilization of organic compounds as sole carbon sources were done with BMS-N medium without bromocresol purple. The different carbon sources were added to give final concentrations of $0.1 \%$ (wt/vol).

Tyrosine, DL-norleucine, testosterone, $p$-hydroxybenzoic acid, and sebacic acid were autoclaved; the remaining organic compounds were sterilized by filtration.

Growth on the inoculated media was recorded after 8,16 , 30 , and 48 days. The last scoring was after 3 months. The test was considered positive if growth in the test dish was greater than growth in the control dish without any carbon source.

The tests for utilization of organic compounds as sole carbon and nitrogen sources were carried out in basal medium BMS, which contained $0.5 \mathrm{~g}$ of $\mathrm{KH}_{2} \mathrm{PO}_{4}, 1.5 \mathrm{~g}$ of $\mathrm{K}_{2} \mathrm{HPO}_{4} \cdot 3 \mathrm{H}_{2} \mathrm{O}, 0.2 \mathrm{~g}$ of $\mathrm{KCl}, 0.2 \mathrm{~g}$ of $\mathrm{MgSO}_{4} \cdot 7 \mathrm{H}_{2} \mathrm{O}, 25 \mathrm{~g}$ of $\mathrm{NaCl}, 15.0 \mathrm{~g}$ of agar no. 1 (Oxoid), and $1,000 \mathrm{ml}$ of distilled water $(\mathrm{pH} 7.0)$. The amino acids L-serine, $\mathrm{L}-\alpha$-alanine, and glucosamine were sterilized by filtration and were added to the sterile medium to give final concentrations of $0.1 \%$ (wt/vol). 
TABLE 1. List of strains used in this study

\begin{tabular}{|c|c|c|c|c|}
\hline Cluster & $\begin{array}{c}\text { Serial } \\
\text { no. }\end{array}$ & Name or laboratory no. & Source or location of sediment sample & $\begin{array}{l}\text { Depth of sediment } \\
\text { sample }(\mathrm{m})\end{array}$ \\
\hline \multirow[t]{17}{*}{1} & 1 & $2808 \mathrm{~W}$ & $25^{\circ} 36^{\prime} \mathrm{N}, 16^{\circ} 07^{\prime} \mathrm{W}$ & 940 \\
\hline & 2 & $1801 \mathrm{~W}$ & $36^{\circ} 47^{\prime} \mathrm{N}, 14^{\circ} 16^{\prime} \mathrm{W}$ & 408 \\
\hline & 3 & $2708 \mathrm{~W}$ & $46^{\circ} 58^{\prime} \mathrm{N}, 05^{\circ} 13^{\prime} \mathrm{W}$ & 160 \\
\hline & 4 & $3228 \mathrm{~W}$ & $80^{\circ} 10^{\prime} \mathrm{N}, 11^{\circ} 10^{\prime} \mathrm{E}$ & 197 \\
\hline & 5 & $4578 \mathrm{~W}$ & Jacotet Bay, Mauritius & 5 \\
\hline & 6 & $3438 \mathrm{~W}^{\mathrm{T}}$ & $51^{\circ} 30^{\prime} \mathrm{N}, 30^{\circ} 19^{\prime} \mathrm{W}$ & 1,400 \\
\hline & 7 & $7579 W$ & $52^{\circ} 16^{\prime} \mathrm{N}, 31^{\circ} 00^{\prime} \mathrm{W}$ & 700 \\
\hline & 8 & $4169 \mathrm{~W}$ & $76^{\circ} 18^{\prime} \mathrm{N}, 11^{\circ} 32^{\prime} \mathrm{E}$ & 2,800 \\
\hline & 9 & $7584 \mathrm{~W}$ & $52^{\circ} 16^{\prime} \mathrm{N}, 31^{\circ} 00^{\prime} \mathrm{W}$ & 700 \\
\hline & 10 & $4140 \mathrm{~W}$ & $53^{\circ} 18^{\prime} \mathrm{N}, 34^{\circ} 39^{\prime} \mathrm{W}$ & 1,680 \\
\hline & 11 & $5216 \mathrm{~W}$ & Bethy's Bay, Republic of South Africa & 12 \\
\hline & 12 & $2834 \mathrm{~W}$ & $33^{\circ} 40^{\prime} \mathrm{N}, 09^{\circ} 09^{\prime} \mathrm{W}$ & 1,750 \\
\hline & 13 & $4412 \mathrm{~W}$ & $78^{\circ} 26^{\prime} \mathrm{N}, 07^{\circ} 06^{\prime} \mathrm{E}$ & 3,000 \\
\hline & 14 & $4251 \mathrm{~W}$ & $75^{\circ} 36^{\prime} \mathrm{N}, 13^{\circ} 29^{\prime} \mathrm{E}$ & 1,025 \\
\hline & 15 & $3609 \mathrm{~W}$ & $70^{\circ} 20^{\prime} \mathrm{N}, 15^{\circ} 24^{\prime} \mathrm{E}$ & 2,342 \\
\hline & 16 & $4170 \mathrm{~W}$ & $76^{\circ} 49^{\prime} \mathrm{N}, 12^{\circ} 01^{\prime} \mathrm{E}$ & 1,208 \\
\hline & 17 & $2863 \mathrm{~W}$ & $47^{\circ} 18^{\prime} \mathrm{N}, 06^{\circ} 32^{\prime} \mathrm{W}$ & 1,100 \\
\hline ? & 18 & $5075 \mathrm{~W}$ & Coastal soil, Seychelles & \\
\hline$?$ & 19 & $4599 \mathrm{~W}$ & Coastal soil, Mauritius & \\
\hline \multirow[t]{2}{*}{2} & 20 & Mycobacterium smegmatis & DSM $43078^{a}$ & \\
\hline & 21 & Mycobacterium phlei & DSM 43214 & \\
\hline$?$ & 22 & Nocardia asteroides & DSM 43003 & \\
\hline \multirow[t]{9}{*}{3} & 23 & Rhodococcus sp. (Hüls AG, Marl; "Nocardia corallina") & DSM 43001 & \\
\hline & 24 & R. rhodochrous (K. Schaal N27; "Nocardia rubra") & DSM 43008 & \\
\hline & 25 & $R$. rhodochrous & DSM $43241^{\mathrm{T}}$ & \\
\hline & 26 & $1732 \mathrm{R}$ & $34^{\circ} 01^{\prime} \mathrm{N}, 15^{\circ} 19^{\prime} \mathrm{W}$ & 3,920 \\
\hline & 27 & $666 \mathrm{R}$ & $51^{\circ} 26^{\prime} \mathrm{N}, 02^{\circ} 28^{\prime} \mathrm{E}$ & 34 \\
\hline & 28 & $3609 \mathrm{R}$ & $70^{\circ} 20^{\prime} \mathrm{N}, 15^{\circ} 24^{\prime} \mathrm{E}$ & 2,342 \\
\hline & 29 & $4107 \mathrm{R}$ & $52^{\circ} 24^{\prime} \mathrm{N}, 31^{\circ} 30^{\prime} \mathrm{W}$ & 1,080 \\
\hline & 30 & $2863 R$ & $47^{\circ} 18^{\prime} \mathrm{N}, 06^{\circ} 32^{\prime} \mathrm{W}$ & 1,100 \\
\hline & 31 & $4020 \mathrm{R}$ & $79^{\circ} 18^{\prime} \mathrm{N}, 11^{\circ} 40^{\prime} \mathrm{E}$ & 200 \\
\hline \multirow[t]{4}{*}{4} & 32 & $\begin{array}{l}\text { R. erythropolis Metcalf and Brown } 1957 \text { (= ATCC 19369); } \\
\text { ("Nocardia calcarea") }\end{array}$ & DSM 43188 & \\
\hline & 33 & $R$. erythropolis & DSM $43066^{\mathrm{T}}$ & \\
\hline & 34 & R. erythropolis (L. Ettlinger LBG A3116; "Nocardia opaca”) & DSM 43135 & \\
\hline & 35 & Nocardia sp. (H. Reichenbach; "Nocardia flava") & DSM 43069 & \\
\hline$?$ & 36 & $\begin{array}{l}\text { Nocardia sp. (A. Seino KCC A0019; "Nocardia } \\
\text { polychromogenes") }\end{array}$ & DSM 43022 & \\
\hline ? & 37 & Nocardioides albus & DSM $43109^{\mathrm{T}}$ & \\
\hline
\end{tabular}

${ }^{a}$ DSM, Deutsche Sammlung für Mikroorganismen, Göttingen, Federal Republic of Germany.

${ }^{b}$ See reference 7 .

Utilization was considered positive if growth in the medium containing the amino acid was greater than growth in the control medium without the amino acid. These tests were examined together with the tests for sole carbon sources.

Tests for hydrolysis of adenine $(0.5 \%$, wt $/ \mathrm{vol})$, guanine $(0.5 \%, \mathrm{wt} / \mathrm{vol})$, tyrosine $(0.5 \%$, wt $/ \mathrm{vol})$, keratin $(0.5 \%$, $\mathrm{wt} / \mathrm{vol})$, xanthine $(0.4 \%$, wt/vol $)$, hypoxanthine $(0.4 \%$, $\mathrm{wt} / \mathrm{vol}$ ), and casein were performed by the method of Gordon et al. (15).

Hydrolysis of Tween 40 , Tween 60 , and Tween 80 was investigated by the method of Sierra (29).

Degradation of starch and chitin was examined by the method of Weyland et al. (37).

Cellulose degradation was examined in a medium containing $0.5 \mathrm{~g}$ of $\mathrm{NaNO}_{3}, 0.01 \mathrm{~g}$ of $\mathrm{FeSO}_{4} \cdot 7 \mathrm{H}_{2} \mathrm{O}, 0.1 \mathrm{~g}$ of $\mathrm{K}_{2} \mathrm{HPO}_{4} \cdot 3 \mathrm{H}_{2} \mathrm{O}, 0.05 \mathrm{~g}$ of $\mathrm{NaHCO}_{3}, 0.25 \mathrm{~g}$ of $\left(\mathrm{NH}_{4}\right)_{2} \mathrm{SO}_{4}$, $0.05 \mathrm{~g}$ of yeast extract (Difco), $15.0 \mathrm{~g}$ of agar (Difco), $10.0 \mathrm{~g}$ of cellulose prepared by the method of Tansey (32), $750 \mathrm{ml}$ of seawater, and $250 \mathrm{ml}$ of distilled water $(\mathrm{pH} \mathrm{7.0)}$. The heavily inoculated plates were examined for clearing zones around or beneath the colonies.

Hydrolysis of cellulose, in the form of paper (Whatman no. 5) and cellophane (Kalle, Wiesbaden, Federal Republic of Germany), and hydrolysis of esculin disks (Becton, Dickinson \& Co., Rutherford, N.J.) and gelatin (charcoal gelatin disks; Oxoid) were examined in modified ZoBell medium (37). Hydrolysis was considered positive if the paper or cellophane was degraded, if the charcoal was released from the gelatin, or if the esculin disk colored the medium blackish brown.

All hydrolysis tests were recorded weekly for 5 weeks, with the final reading taken after 2 months. Starch degradation was analyzed after 5 weeks.

Catalase, oxidase, and urease were examined by the method of Weyland et al. (37). Formation of nitrate reductase was determined in yeast extract-malt extract medium containing $1.5 \mathrm{~g}$ of $\mathrm{KNO}_{3}$ per liter. Formation of nitrite was detected with Griess-Ilosvay reagent after 3, 7, and 9 days.

Tests for tolerance to temperature, sodium chloride, $\mathrm{pH}$ and chemical inhibitors were carried out on PYA medium, which contained $10 \mathrm{~g}$ of Bacto-Peptone (Difco), $3 \mathrm{~g}$ of yeast extract (Difco), and $15 \mathrm{~g}$ of agar no. 1 (Oxoid). For the $\mathrm{NaCl}$ tests $1,000 \mathrm{ml}$ of distilled water was added. For the remaining tests $750 \mathrm{ml}$ of seawater and $250 \mathrm{ml}$ of distilled water were used. In all tests except the $\mathrm{pH}$ tolerance tests the media were adjusted to $\mathrm{pH} 7.5$. 
We examined the ability of the organisms to grow at temperatures of $3,12,18,24$, and $30^{\circ} \mathrm{C}$, at sodium chloride concentrations of $0,1,3,4,5,7$ and $10 \%(\mathrm{wt} / \mathrm{vol})$, and in a $\mathrm{pH}$ range from 5 to 10 .

In the inhibition tests, different concentrations (see Table 2) of crystal violet, sodium azide, potassium tellurite, phenyl ethanol, and phenol were added to PYA medium. A control culture without any inhibitor was used to estimate unaffected growth.

The results of the tolerance and inhibition tests were recorded after $1,2,4$, and 8 weeks.

Resistance to lysozyme was determined by a modification of the method of Mordarska et al. (22). The incubation time after lysozyme (E. Merck AG, Darmstadt, Federal Republic of Germany) was added was extended to $6 \mathrm{~h}$, and the incubation temperature was lowered to $24^{\circ} \mathrm{C}$.

Susceptibility to penicillin was analyzed by using filter paper disks saturated with 2 and $10 \mathrm{IU}$ of penicillin $\mathrm{G}$ (Difco). The disks were placed on yeast extract-malt extract agar inoculated with the different strains tested. The plates were observed for zones of growth inhibition around the disks after incubation periods of 3 and 10 days at $18^{\circ} \mathrm{C}$. The tests for susceptibility to vancomycin and rifampin were carried out in the same manner, but the filter disks were prepared by using the method of Goodfellow and Orchard (13). The filter disks were soaked with a solution containing $50 \mu \mathrm{g}$ of vancomycin (Serva) per $\mathrm{ml}$ or $50 \mu \mathrm{g}$ of rifampin (Serva) per $\mathrm{ml}$.

Morphological and cultural tests. Macroscopic growth was examined on yeast extract-malt extract agar plates, generally after incubation for 2 weeks (after good growth had occurred).

For microscopic observations, the slide culture technique of Williams and Cross (38) was used. Micrographs were obtained with a Zeiss Universal microscope, using phaseand interference-contrast equipment.

Chemotaxonomic tests. The amino acid, amino sugar, and monosaccharide components of cell wall fragments were determined by the method of Richter (27).

Mycolic acids were detected by performing a thin-layer chromatographic analysis of ethanol-diethyl ether extracts, using the method of Minnikin et al. (21).

Menaquinones were extracted and purified as described by Collins et al. (2). The purified menaquinones were examined by reverse-phase and silver ion-impregnated thinlayer chromatography $(3,16)$.

The guanine-plus-cytosine $(\mathrm{G}+\mathrm{C})$ contents of the deoxyribonucleic acids (DNAs) were calculated from the melting temperatures by using the formula of De Ley (4). The cells were cultivated and lysed by the method of Bourgeois and Beaman (1). The DNA was isolated by the method of Marmur (19). The melting temperature of the DNA was determined by the method of Marmur and Doty (20), using a Gilford model 250 spectrophotometer equipped with a Gilford model 2524 thermoprogrammer. DNA from Escherichia coli $\mathrm{K}-12$ was used as a standard.

Computer analysis. The test organisms listed in Table 1 were screened for 106 unit characters. Final test readings were used for computation. A total of 22 characters gave either all positive or all negative results, and, as they had no discriminating value, these characters were omitted from the data matrix. A total of 84 unit characters (Table 2) were scored for computation by recording positive reactions as 2 , negative reactions as 0 , and weak positive reactions as 1 .

The data were analyzed with a Nova model 1200 computer by using the Clust 6 program of $\mathrm{H}$. Krause (Institut für
Meeresforschung Bremerhaven, Bremerhaven, Federal Republic of Germany). The subroutines necessary were obtained from Steinhausen and Langer (31). The betweenstrain similarities were calculated by using the euclidean distances. The cluster analysis was carried out by using the following eight methods: (i) single linkage; (ii) complete linkage; (iii) unweighted average linkage; (iv) weighted average linkage; (v) median method; (vi) centroid method; (vii) Wards method; and (viii) Lance-Williams method (17).

\section{RESULTS}

Numerical taxonomic analysis. Cluster analyses carried out with different methods (see above) produced rather similar results. Figure 1 shows the dendrogram derived by the unweighted average linkage cluster method. At the $80 \%$ similarity level there were four clusters, which contained 31 of the 37 strains tested.

(i) Cluster 1. Of the 19 cream-colored marine strains studied, 17 formed a homogeneous cluster with a relatively high intergroup similarity. This cluster did not contain any of the marker strains and was well separated from the other clusters. Therefore, it seems reasonable to equate cluster 1 with a new species.

Strain $5075 \mathrm{~W}$, one of the two cream-colored strains that were obtained not from the sea but from littoral sites, was only marginally included in cluster 1 , and strain $4599 \mathrm{~W}$ could not be allocated to any of the four clusters.

(ii) Cluster 2. Cluster 2 contained only the two reference strains of the genus Mycobacterium.

(iii) Cluster 3. The red or orange marine isolates formed a cluster together with the type strain of Rhodococcus rhodochrous, another strain (serial no. 24) of this species (previously labeled "Nocardia rubra"), and a Rhodococcus sp. strain (serial no. 23; formerly named "Nocardia corallina"). Four of the red or orange marine isolates showed a high affinity to the three marker strains, whereas strains $666 \mathrm{R}$ and $1732 \mathrm{R}$ were linked to the members of cluster 3 just above the $80 \%$ similarity level.

(iv) Cluster 4. The strains of Rhodococcus erythropolis were recovered in cluster 4 . We found high affinity between the type strain (DSM 43066) and two other strains (DSM 43135 and DSM 43188) of this species (formerly labeled "Nocardia opaca" and "Nocardia calcarea," respectively). The latter designations have been reduced to synonyms of $R$. erythropolis by Goodfellow et al. (7). At a somewhat lower similarity level a Nocardia sp. strain (serial no. 35; "Nocardia flava") joined cluster 4.

The position of the marker strain Nocardia sp. (serial no. 36; "Nocardia polychromogenes") was dependent on the kind of cluster analysis method used. "Nocardia polychromogenes" was attached to the strains of cluster 4 or grouped together with Nocardia asteroides. In no case was the strain closely positioned to strains assigned to cluster 1 .

Morphology and growth requirement. The strains of cluster 1 grew very slowly. Optimal growth occurred in media with a seawater content of 75 to $100 \%$ or with adequate salinity. On media prepared with distilled water no growth or only very scarce mycelia developed. The optimal growth temperature was about $20^{\circ} \mathrm{C}$. Temperatures above $30^{\circ} \mathrm{C}$ inhibited growth almost completely, whereas fair growth occurred at $5^{\circ} \mathrm{C}$ after a relatively short incubation.

Under optimal growth conditions the strains formed welldeveloped branched primary mycelia (Fig. 2A through D), which fragmented after about 14 days into bacillary and coccoid elements (Fig. 3A through C). Aerial mycelia and diffusible pigments were not formed. 


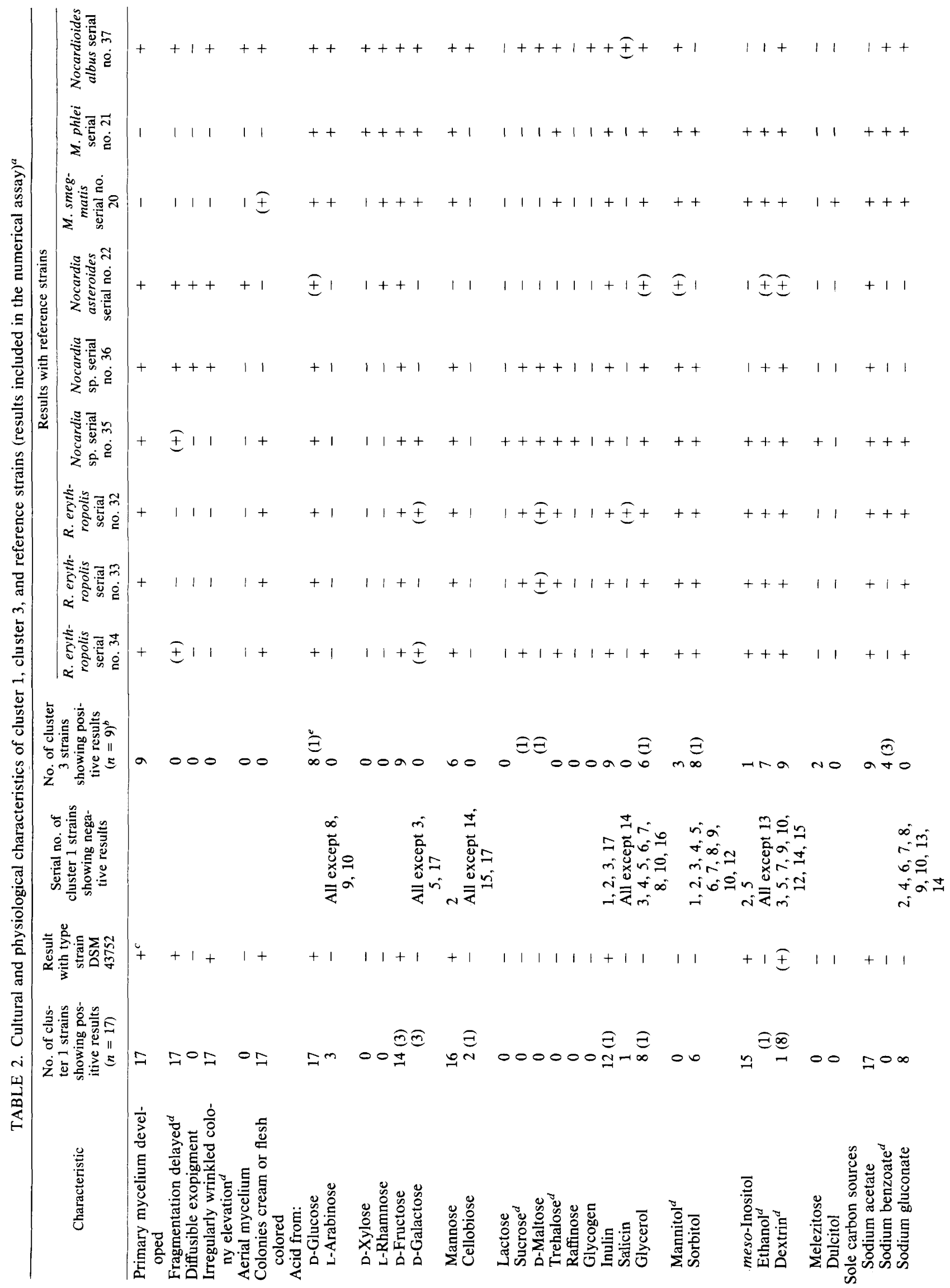




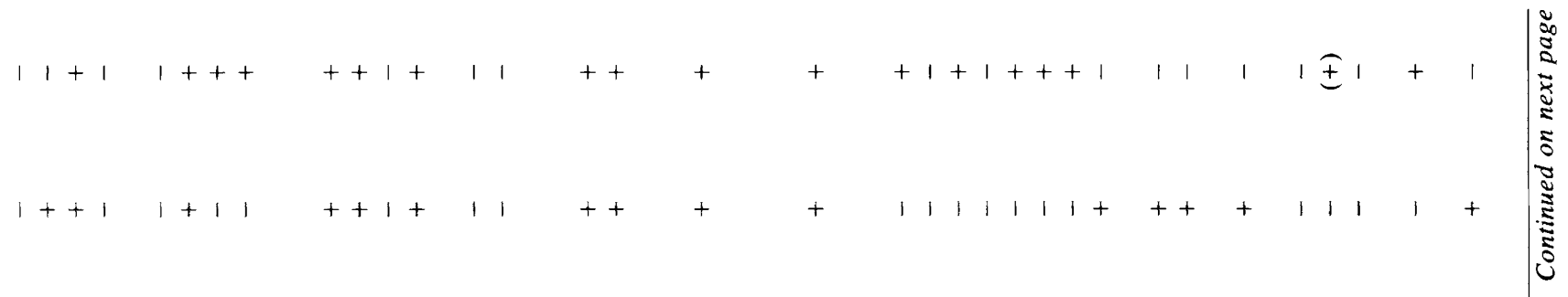

$$
\begin{aligned}
& 1++ \text { I } 1+11 \text { 王玨王 } 1 \text { 王王 } 1011111111+++111+\text { 王 } \\
& 1+ \pm 1 \quad 1111 \quad 111++1 \quad 11 \text { 王 } 1 \quad 111111111+ \pm+11++
\end{aligned}
$$

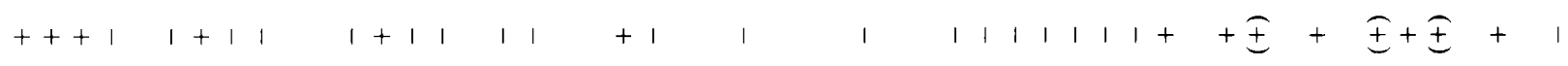

$$
\begin{aligned}
& +++1++++++++1++ \text { 王 } 1 \text { 1 } 1111+11+1+1+\text { I }+1 \\
& +++1 \quad 1+++++1++1+\text { 王王 } 1 \quad 111+1+1++ \pm+1+1+1 \\
& +++1++++++1++1+\text { 王 } 1 \quad 111+1+1 \text { I }+1+1+1+1
\end{aligned}
$$

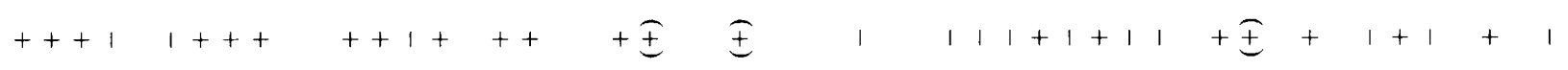

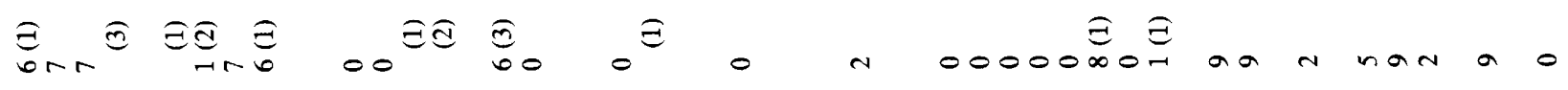

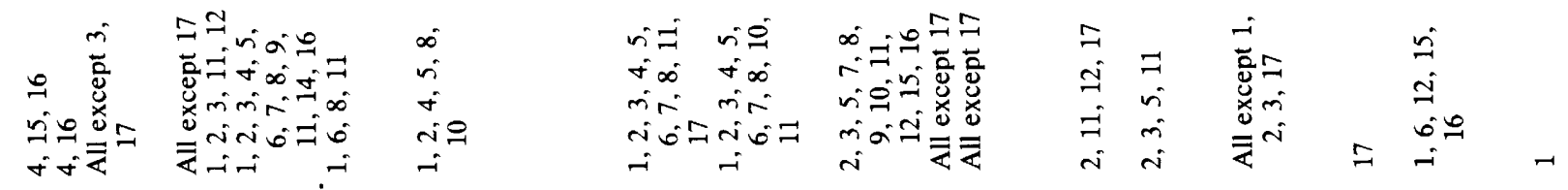

$$
\begin{aligned}
& 1++1 \quad 11+1 \quad 1+1 \text { 王 } 11+1 \quad 1 \quad £ \quad 11111+1++1+1++1++
\end{aligned}
$$

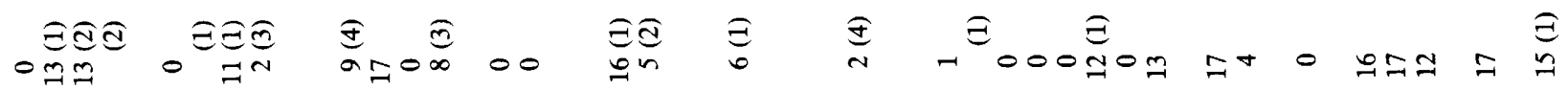

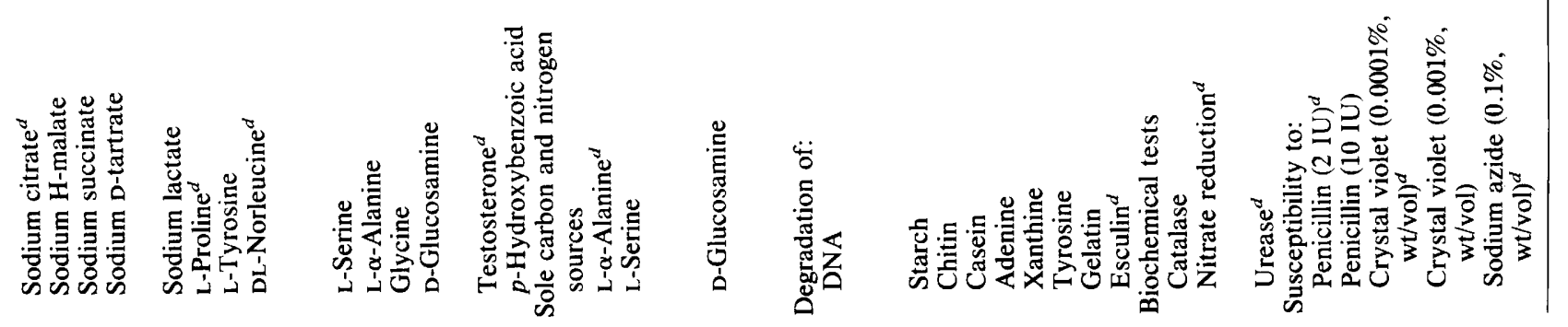




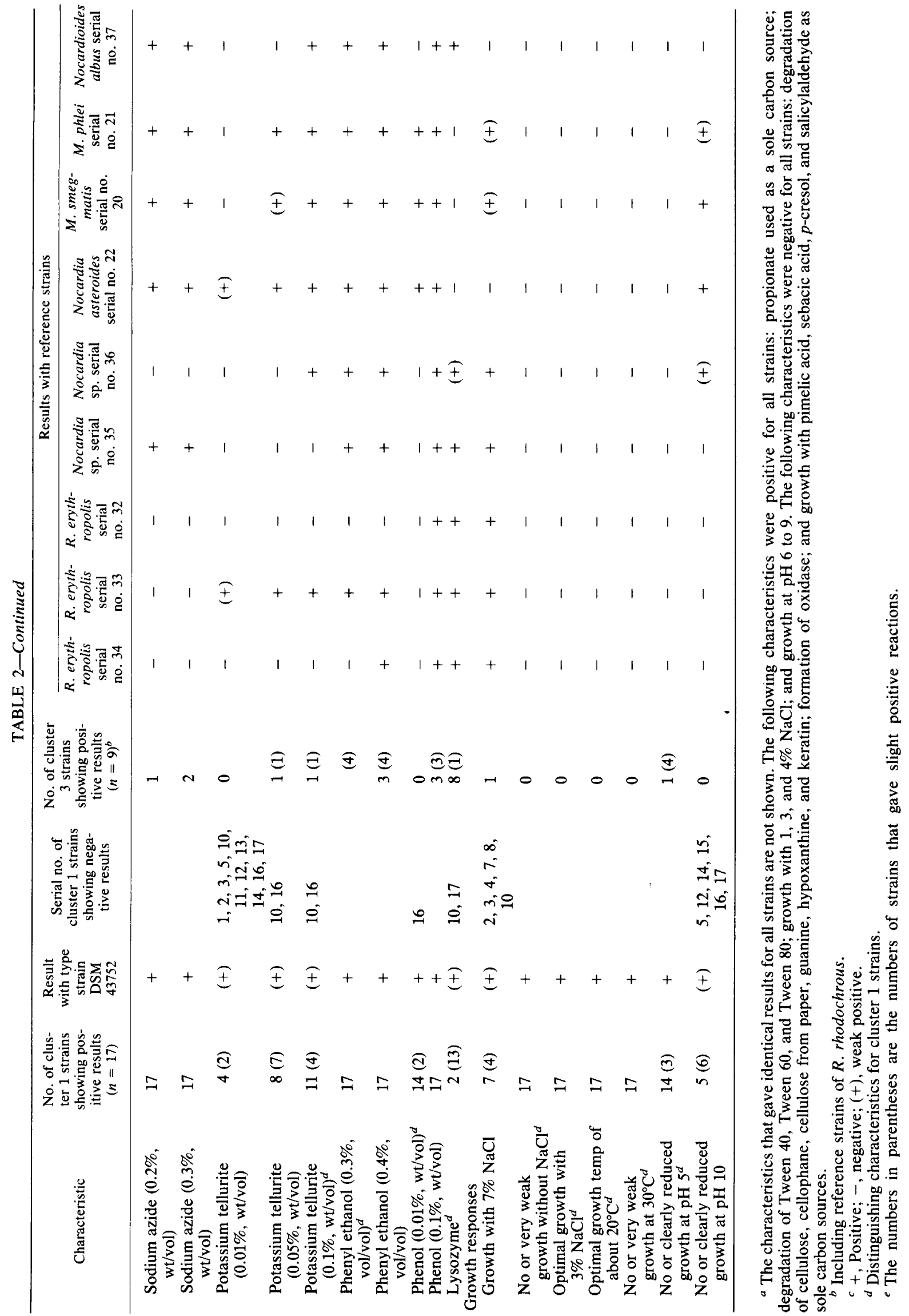




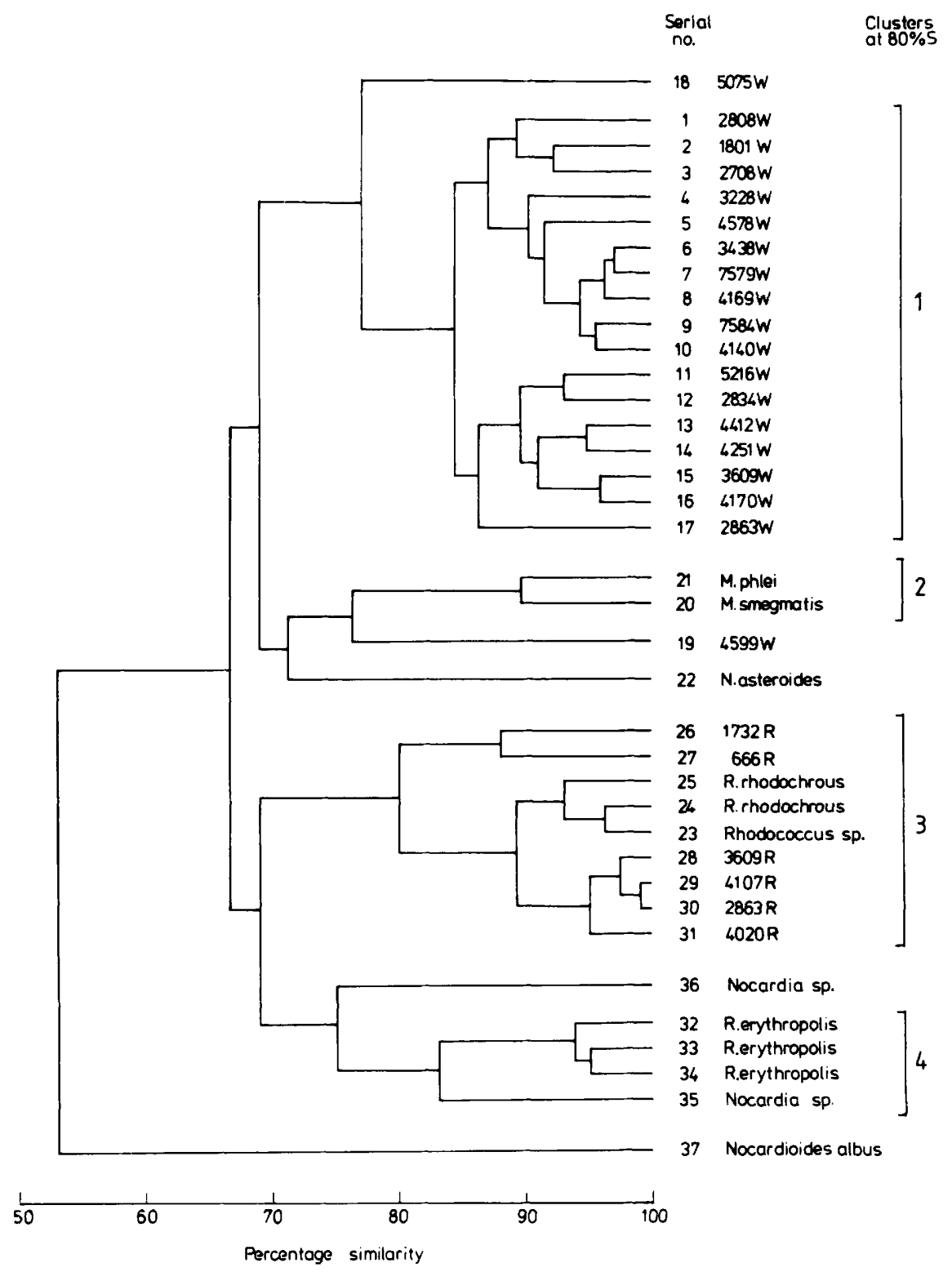

FIG. 1. Dendrogram derived by the unweighted average linkage method. S, Similarity.

The aerobic strains were nonmotile, gram positive, and partially acid fast. Endospores were not formed, but after long incubation swollen cells (Fig. 2E and F) were observed.

The colonies were cream colored, sometimes with a tinge of pink. Red- or orange-pigmented colonies were never observed even after longer exposure to light. The colonies were irregularly wrinkled with lobate margins and were not easy to emulsify (Fig. 3D).

Physiology. The physiological properties of the cluster 1 strains are listed in Table 2 , which includes all of the results used in the numerical assay. The features which are useful in distinguishing the strains in this cluster from the remaining strains tested are indicated. The following characters had a high discriminating value: no acid production from sucrose, trehalose, mannitol, or ethanol; no or poor growth with sodium benzoate, sodium citrate, proline, DL-norleucine, or testosterone as a sole carbon source but growth with $\mathbf{L - \alpha}-$ alanine as a sole carbon and nitrogen source; no reduction of nitrate to nitrite; no hydrolysis of urea, but degradation of esculin. The cluster 1 strains were further defined by their high susceptibilities to the antibiotic penicillin, rifampin, and vancomycin and the inhibitors crystal violet, sodium azide, phenol, phenyl ethanol, and potassium tellurite. On the other hand, they exhibited relatively low susceptibilities to lysozyme.

Chemotaxonomy. Purified cell walls of all cluster 1 strains contained meso-diaminopimelic acid and large amounts of arabinose and galactose, which is consistent with a type IV cell wall composition sensu Lechevalier and Lechevalier (18).

In thin-layer chromatography analyses of ethanol-diethyl ether extracts of the cluster 1 strains, mycolic acid spots were found. The $R_{f}$ values of these spots were similar to those of the mycolic acid spots of Nocardia asteroides and two Nocardia sp. strains (serial no. 35 ["Nocardia flava"] and serial no. 36 ["N. polychromogenes"']). These mycolic 

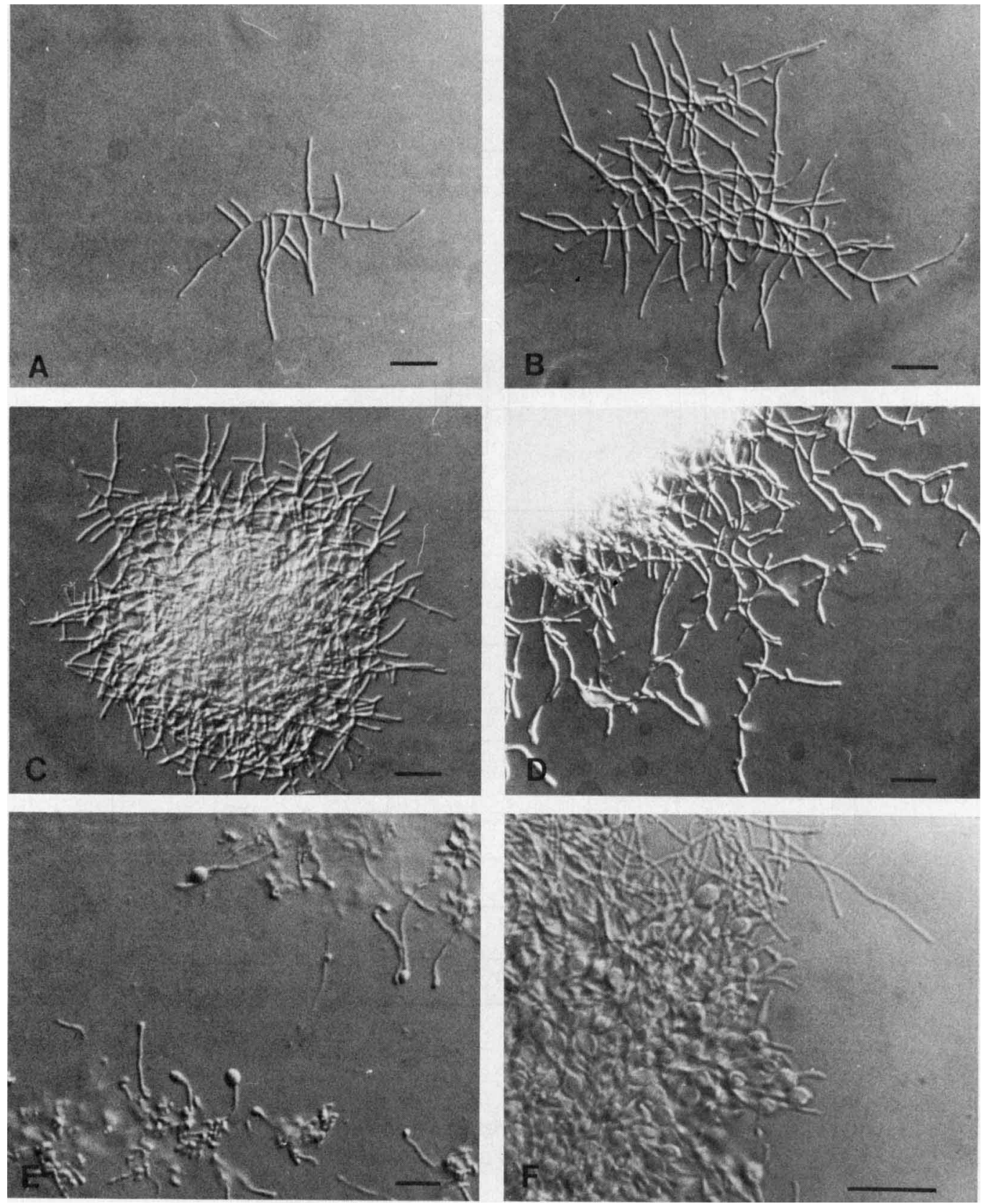

FIG. 2. $R$. marinonascens strain $3438 \mathrm{~W}^{\mathrm{T}}$ (= DSM $43752^{\mathrm{T}}$ ): slide microculture on yeast extract-malt extract-seawater medium at a growth temperature of $18^{\circ} \mathrm{C}$. Interference contrast micrographs of substrate mycelium and microcolony development. (A) Developing mycelium after 4 days of cultivation. (B) Mycelium after 8 days. (C) Microcolony after 12 days of cultivation. (D) Colony margin after 16 days of cultivation. ( $\mathrm{E}$ and F) Swelling of hyphal apices at the edges of some microcolonies after 24 days of cultivation. Bar $=10 \mu \mathrm{m}$.

acids could be classified as group $C$ types according to the definition of Minnikin et al. (21). The mycolic acids of $R$. rhodochrous (serial no. 25) and $R$. erythropolis (serial no. 23) were determined as group B types.

The menaquinone pattern was also analyzed by thin-layer chromatography. Four cluster 1 strains (strains $2834 \mathrm{~W}$, $3438 \mathrm{~W}, 4251 \mathrm{~W}$, and $4412 \mathrm{~W}$ ) were tested. These strains contained menaquinones with eight isoprene units and one hydrogenated double bond as the most prevalent type (Table 3).

The $\mathrm{G}+\mathrm{C}$ contents of the DNAs were analyzed by thermal denaturation of five cream-colored strains (strains $1801 \mathrm{~W}$,
$2834 \mathrm{~W}, 2863 \mathrm{~W}, 3438 \mathrm{~W}$, and $4251 \mathrm{~W})$; the values obtained ranged from 64.9 to 66.4 mol\% (Table 3). Table 4 compares the diagnostic characteristics of cluster 1 with the properties of Rhodococcus and Nocardia species.

Distribution. Cream-colored nocardioform cluster 1 strains have so far been found only in marine habitats. They were isolated from the top layers of marine sediments from various sea sites including the Iberian Sea, the Bay of Biscay, the North Sea, and off northwest Africa, but they were more frequent in northern sea areas (Norwegian Sea, Barents Sea, North Atlantic Ridge, and off the Faeroe Islands). The highest numbers were obtained from the areas 

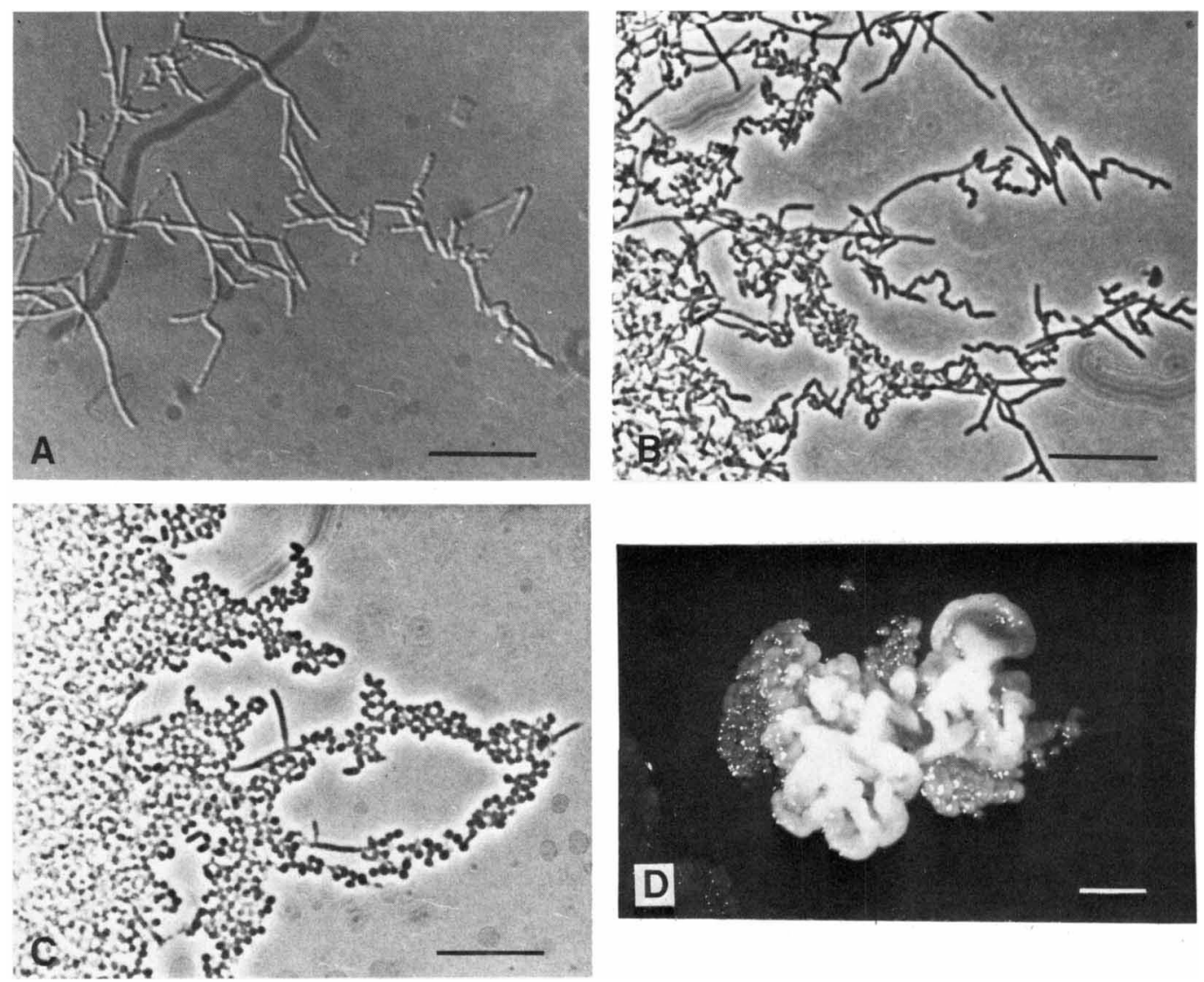

FIG. 3. $R$. marinonascens strain $3438 \mathrm{~W}^{\mathrm{T}}$ ( $=\mathrm{DSM} 43752^{\mathrm{T}}$ ) grown at $18^{\circ} \mathrm{C}$ on yeast extract-malt extract-seawater medium. (A through C) Slide microculture. Bar $=10 \mu \mathrm{m}$. (A) Beginning of fragmentation of the mycelium: mutually dislocating elements after 21 days of cultivation. Interference-contrast microscopy. (B) Progressive fragmentation at the edge of a colony after 22 days of cultivation. Phase-contrast microscopy. (C) Advanced stage of fragmentation into coccoid elements after 25 days of cultivation. Phase-contrast microscopy. (D) Elevated colony growth of a 21-day macroculture. Bar $=1 \mathrm{~mm}$.

that were least influenced by land and from depths ranging up to $2,000 \mathrm{~m}(35)$.

\section{DISCUSSION}

Our numerical phenetic assay indicated that there is a close relationship between the red or orange marine isolates and the type strain of $R$. rhodochrous, as well as another strain of this species and Rhodococcus sp. strain DSM 43001. The latter two organisms were formerly labeled "Nocardia rubra" and "Nocardia corallina", respectively. The three reference strains cluster very closely together, confirming their reclassification as Rhodococcus species. The relatively high general similarity between four of the red or orange isolates and the marker strains is also supported by chemotaxonomic data; strain $4020 \mathrm{R}$ (serial no. 31) contains MK-8 $\left(\mathrm{H}_{2}\right)$ as the prevalent menaquinone, mycolic acids of group B sensu Minnikin et al. (21), and DNA with a $G+C$ content of $70.7 \mathrm{~mol} \%$. Supplementary tests will be necessary to establish whether the red or orange isolates are variants of $R$. rhodochrous.

Further work will also be needed to throw more light on the taxonomic status of red or orange strains $666 \mathrm{R}$ and 1732R.

In contrast to the red or orange marine nocardioform isolates, the cream-colored marine nocardioform isolates form a homogeneous, well-separated cluster which does not include any of the reference species. Regarding generic status, the cluster 1 strains with $\mathrm{G}+\mathrm{C}$ contents above 60 mol\%, with nocardomycolic acids of group C sensu Minnikin et al. (21), and with long-lasting well-developed mycelia can be clearly distinguished from the genera Corynebacterium and Mycobacterium. The numerical phenetic data, together with the data derived from chemical studies, indicate a close relationship between these strains and the genera Nocardia and Rhodococcus.

When the diagnostic characters of the genera Rhodococcus $(5,6,12,13)$ and Nocardia (12) are compared with the properties of cluster 1 strains (Table 4), the intermediate position of cluster 1 between Rhodococcus and Nocardia species becomes apparent. The affinity of this cluster to the genus Nocardia is underlined by morphological and colonial features, relatively low lysozyme susceptibility, and high susceptibility to phenol, sodium azide, crystal violet, and phenyl ethanol, as well as the presence of group $\mathrm{C}$ mycolic acids. Support for the classification of these strains in the genus Rhodococcus is based upon the lack of aerial mycelia and a diffusible exopigment, high susceptibility to penicillin, rifampin, and vancomycin, and the presence of menaquinones with eight isoprene units and one hydrogenated double bond.

The $\mathrm{G}+\mathrm{C}$ content of the DNA is of secondary importance for generic classification into the taxa Rhodococcus and Nocardia. The $\mathrm{G}+\mathrm{C}$ contents of the cluster 1 strains $(64.9$ to $66.4 \mathrm{~mol} \%$ ) fall within the narrow range for the genus 


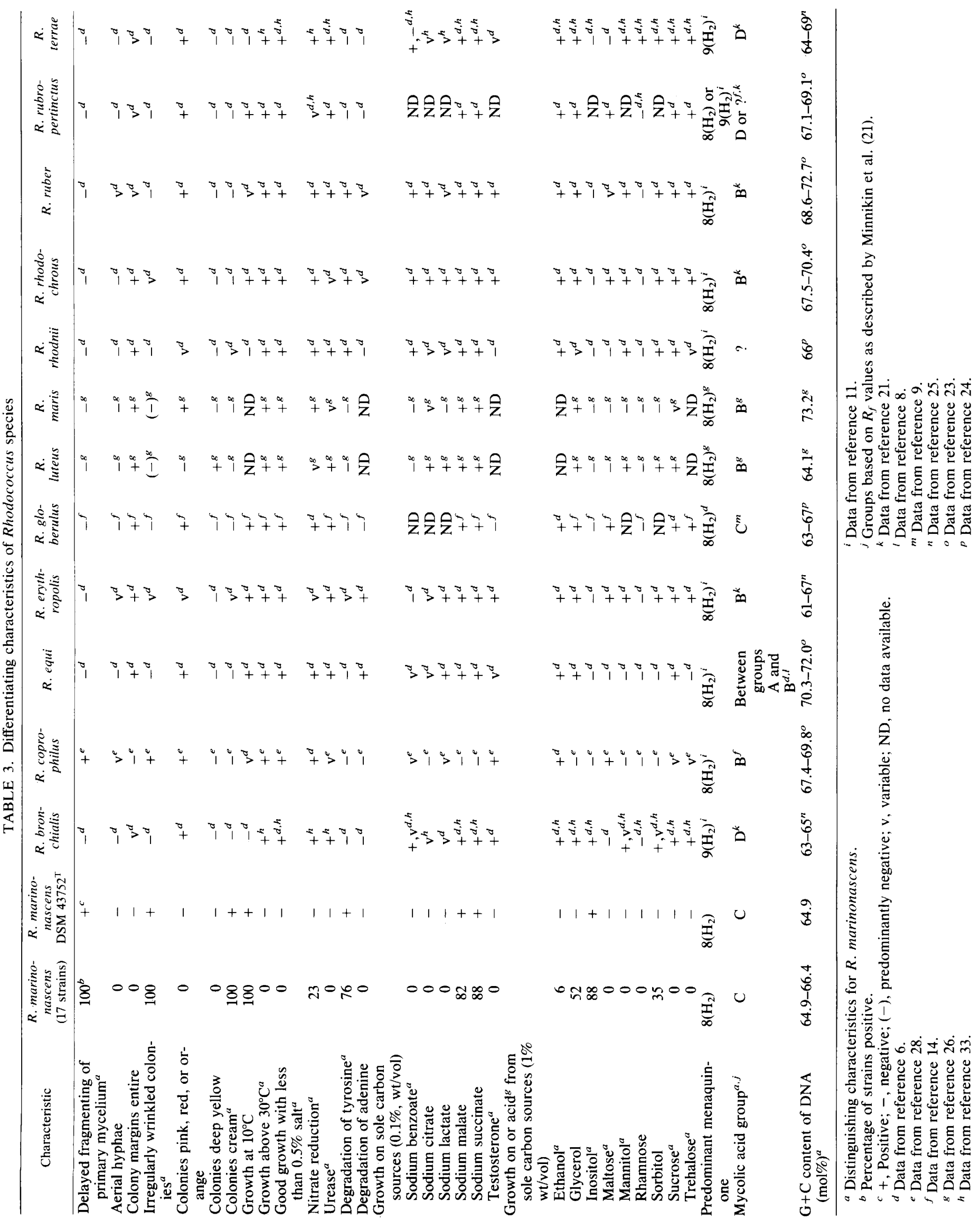


TABLE 4. Diagnostic characteristics of the genera Rhodococcus and Nocardia compared with the properties of cluster 1

\begin{tabular}{|c|c|c|c|}
\hline Characteristic & Rhodococcus ${ }^{a}$ & Cluster 1 & Nocardia $^{b}$ \\
\hline Aerobic & + & + & + \\
\hline Gram positive & + & + & + \\
\hline Primary mycelium & + & + & + \\
\hline Well-branched mycelium & - & + & + \\
\hline Soon fragmenting & + & - & - \\
\hline Colony elevation irregular & - & + & + \\
\hline Colonies easy to emulsify & + & - & - \\
\hline Entire margin & + & - & - \\
\hline Aerial hyphae & - & - & + \\
\hline Diffusible exopigment & - & - & + \\
\hline $\begin{array}{l}\text { Wide range of carbon } \\
\text { sources can be utilized }\end{array}$ & + & - & - \\
\hline Lysozyme susceptible & + & $(-)$ & - \\
\hline Penicillin susceptible & + & + & - \\
\hline Vancomycin susceptible & t & + & -. \\
\hline Rifampin susceptible & + & + & - \\
\hline Cell wall type & IV & IV & IV \\
\hline Mycolic acids ${ }^{c}$ & $\begin{array}{l}\text { Mostly } \\
\text { group B }\end{array}$ & Group C & Group C \\
\hline $\begin{array}{l}\text { Prevalent menaquinone } \\
\text { type }\end{array}$ & $\begin{array}{c}\text { MK-8 }\left(\mathrm{H}_{2}\right) \text { or } \\
\text { MK-9( }\left(\mathrm{H}_{2}\right)\end{array}$ & $\mathrm{MK}-8\left(\mathrm{H}_{2}\right)$ & $\mathrm{MK}-8\left(\mathrm{H}_{4}\right)$ \\
\hline $\begin{array}{l}\mathrm{G}+\mathrm{C} \text { content (mol\%) as } \\
\text { determined by chemical } \\
\text { method }\end{array}$ & $59-69$ & & $64-68$ \\
\hline $\begin{array}{c}\mathrm{G}+\mathrm{C} \text { content }(\mathrm{mol} \%) \text { as } \\
\text { determined by thermal } \\
\text { denaturation method }\end{array}$ & $65-73$ & $64-67$ & \\
\hline
\end{tabular}

${ }^{a}$ Data from references $5,6,12,13$, and 23 .

${ }^{b}$ Data from references $5,10,12$, and 13.

c Analyzed and classified by the method of Minnikin et al. (21).

Nocardia (64 to $68 \mathrm{~mol} \%$, chemical method [10]), as well as the broad range for Rhodococcus species (59 to $69 \mathrm{~mol} \%$, chemical method [10], or 65 to $73 \mathrm{~mol} \%$, thermal denaturation method [23]).

Considering the above criteria for their value in generic classification, we believe that the menaquinone pattern is of greater classification value than the mycolic acids. Mycolic acid spots with $R_{f}$ values similar to those designated as group $\mathrm{C}$ are found in strains other than Nocardia strains. Goodfellow et al. (9) showed that within Rhodococcus, subcluster 1 b accommodates several strains containing group $\mathrm{C}$ mycolic acids. Two Nocardia sp. strains (serial no. 35 ["Nocardia flava"] and serial no. 36 ["Nocardia polychromogenes"]) which were included as marker strains in this study are representative organisms with group $\mathrm{C}$ mycolic acids but no clear relationship to the genus Nocardia. Although the strains of cluster 1 resemble in this regard the two marker strains, the numerical phenetic data fail to show much affinity between strains of the two groups. In contrast to differences in mycolic acids, the menaquinone pattern is a more specific criterion for generic classification to Nocardia or Rhodococcus. The cluster 1 strains contain $\mathrm{MK}-8\left(\mathrm{H}_{2}\right)$ as the prevalent quinone type. To our knowledge, $\mathrm{MK}-8\left(\mathrm{H}_{2}\right)$ has never been found as a main menaquinone component in true Nocardia species, which usually possess MK-8( $\left.\mathrm{H}_{4}\right)$. For this reason, and because of the lack of aerial mycelia and a diffusible pigment and susceptibility to penicillin $\mathrm{G}$, rifampin, and vancomycin, we regard the genus Rhodococcus as an acceptable taxonomic niche for cluster 1 . When characteristics of the previously recognized species of this genus are compared with the morphological, physiological, and chemotaxonomic properties of strains in cluster 1 (Table 3), it is obvious that the cluster 1 strains cannot be equated with any of the previously established Rhodococcus species. Therefore, we consider the strains of cluster 1 a new species within the genus Rhodococcus. Since these strains occur exclusively in marine habitats and possess general features of bacteria indigenous to the sea (36; E. Helmke, Dr. thesis, Universität Braunschweig, Federal Republic of Germany, 1980), we name this organism Rhodococcus marinonascens sp. nov. (ma. ri. no. nas'cens. L. adj. marinus of the sea; L. part. adj. nascens nascent, born; M. L. part. adj. marinonascens nascent in the sea). The type strain of this species is 3438W (= DSM 43752). A taxonomic description is given below.

Description of Rhodococcus marinonascens sp. nov. Aerobic, slow-growing nocardioform actinomycetes that are isolated from marine bottom sediments and are unable to develop in freshwater media and at temperatures above $28^{\circ} \mathrm{C}$. Optimal growth occurs around $20^{\circ} \mathrm{C}$ and in media with a seawater content of 75 to $100 \%$ or an equivalent salt concentration. $R$. marinonascens is gram positive, nonmotile, and partially acid fast and develops well-branched mycelia which fragment into bacillary and coccoid elements on solid media after 14 or more days of incubation. The colonies are cream-colored with a tinge of pink, irregularly wrinkled with lobate margins, and not easy to emulsify. Aerial mycelia and extracellular pigments are not formed. $R$. marinonascens has a type IV cell wall composition and contains group $\mathrm{C}$ mycolic acids sensu Minnekin et al. (21) and $\mathrm{MK}-8\left(\mathrm{H}_{2}\right)$ as the main menaquinone component. The DNA base composition is $64.9 \mathrm{~mol} \% \mathrm{G}+\mathrm{C}$.

$R$. marinonascens produces acid from glucose, fructose, mannose, inulin, and inositol. Unlike many other Rhodococcus species, under the specific test conditions which we used, the strains exhibit no acid formation from sucrose, trehalose, mannitol, or ethanol and only weak acid production from dextrin. Also in contrast to many other Rhodococcus species, $R$. marinonascens cannot utilize sodium benzoate, sodium citrate, L-proline, or testosterone as a sole carbon source, but $\mathbf{L}-\alpha-a$ alanine serves as a sole carbon and nitrogen source. Catalase is formed, whereas oxidase, urease, and nitrate reductase are not produced; esculin can be hydrolyzed. $R$. marinonascens is further characterized by high susceptibility to the antibiotics penicillin $G$, rifampin, and vancomycin and the inhibitors crystal violet, sodium azide, potassium tellurite, phenyl ethanol, and phenol; on the other hand, this organism is relatively resistant to lysozyme.

Type strain: 3438W (= DSM 43752).

\section{ACKNOWLEDGMENTS}

We thank Dörte Englisch, Jutta Jürgens, Antje Lassen, Christiane Lorenzen, Annegret Mädler, Helga Schwarz, and Anke Sander for skillful technical assistance, $\mathrm{H}$. Krause for kind help with computation, M. Gomez for correcting the English manuscript, and R. M. Kroppenstedt Deutsche Sammlung für Mikroorganismen, Section Actinomycetales, Darmstadt, Federal Republic of Germany, for helpful suggestions regarding mycolic acid and menaquinone determinations. We are indebted to all of the individuals and institutes who kindly supported us during our survey of the distribution of actinomycetes in the sediments of various sea areas. We express our gratitude to G. H. Stander and the staff of the Department of Sea Fisheries, Cape Town, Republic of South Africa, for logistic support and laboratory facilities. Special thanks is due to G. Bailey, Sea Fisheries Institute, Cape Town, Republic of South Africa, and to the diving group of that institute and of the University of Cape Town for sediment sampling. Sincere thanks are due to W. D. Oliff, National Institute for Water Research, Council of Scientific and Industrial Research, Durban, Republic of South Africa. We are also grateful to 
S. M. Siegel, Department of Botany, University of Hawaii at Manoa, for the use of his laboratory and to E. C. Evans III, Naval Ocean Systems Center, Kailua, Hawaii, for advice and guidance in mangrove areas. We thank all of the individuals of the Hawaii Undersea Research Laboratory and of the various Departments of the University of Hawaii for generous support. Our gratitude also extends to the officers, crews, and scientific staffs of research vessels for all kinds of assistance at sea. Ship time and space on the F.R.V "Anton Dohrn," the R.V. "Meteor," and the R.V. "Sonne" were provided by the Deutsche Wissenschaftliche Kommission für Meeresforschung, the Deutsche Forschungsgemeinschaft, and the Bundesminister für Forschung und Technologie, respectively.

This work was supported by the Bundesminister für Forschung und Technologie and Bayer AG (project BCT 313, PTB 8315).

\section{LITERATURE CITED}

1. Bourgeois, L., and B. L. Beaman. 1976. In vitro spheroplast and L-form induction within the pathogenic nocardiae. J. Bacteriol. 127:584-594.

2. Collins, M. D., T. Pirouz, and M. Goodfellow. 1977. Distribution of menaquinones in actinomycetes and corynebacteria. J. Gen. Microbiol. 100:221-230.

3. Collins, M. D., H. N. Shah, and D. E. Minnikin. 1980. A note on the separation of natural mixtures of bacterial menaquinones using reverse phase thin-layer chromatography. J. Appl. Bacteriol. 48:277-282.

4. De Ley, J. 1970. Reexamination of the association between melting point, buoyant density, and chemical base composition of deoxyribonucleic acid. J. Bacteriol. 101:738-754.

5. Goodfellow, M. 1971. Numerical taxonomy of some nocardioform bacteria. J. Gen. Microbiol. 69:33-80.

6. Goodfellow, M., and G. Alderson. 1977. The actinomycete genus Rhodococcus: a home for the 'rhodochrous' complex. J. Gen. Microbiol. 100:99-122.

7. Goodfellow, M., A. R. Beckham, and M. D. Barton. 1982. Numerical classification of Rhodococcus equi and related actinomycetes. J. Appl. Bacteriol. 53:199-207.

8. Goodfellow, M., M. D. Collins, and D. E. Minnikin. 1976. Thinlayer chromatographic analysis of mycolic acid and other longchain components in whole-organisms methanolysates of coryneform and related taxa. J. Gen. Microbiol. 96:351-358.

9. Goodfellow, M., A. Lind, H. Mordarska, S. Pattyn, and M. Tsukamura. 1974. A co-operative numerical analysis of cultures considered to belong to the 'rhodochrous' taxon. J. Gen. Microbiol. 85:291-302,

10. Goodfellow, M., and D. E. Minnikin. 1978. Numerical and chemical methods in the classification of Nocardia and related taxa. Zentralbl. Bakteriol. Parasitenkd. Infektionskr. Hyg. Abt. 1 Suppl. 6:43-51.

11. Goodfellow, M., and D. E. Minnikin. 1981. Classification of nocardioform bacteria. Zentralbl. Bakteriol. Parasitenkd. Infektionskr. Hyg. Abt. 1 Suppl. 11:7-16.

12. Goodfellow, M., and D. E. Minnikin. 1981. The genera Nocardia and Rhodococcus, p. 2016-2027. In M. P. Starr et al. (ed.), The prokaryotes, vol. 2. Springer-Verlag, Berlin.

13. Goodfellow, M., and V. A. Orchard. 1974. Antibiotic sensitivity of some nocardioform bacteria and its value as a criterion for taxonomy. J. Gen. Microbiol. 83:375-387.

14. Goodfellow, M., C. R. Weaver, and D. E. Minnikin. 1982. Numerical classification of some rhodococci, corynebacteria and related organisms. J. Gen. Microbiol. 128:731-745.

15. Gordon, R. E., D. A. Barnett, J. E. Handerhan, and C. Hor-Nay Pang. 1974. Nocardia coeliaca, Nocardia autotrophica, and the nocardin strain. Int. J. Syst. Bacteriol. 24:54-63.

16. Kroppenstedt, R. M. 1982. Anwendung chromatographischer HP-Verfahren (HPTLC and HPLC) in der Bakterien-Taxonomie. GIT Lab. Med. 5:266-275.

17. Lance, G. H., and W. T. Williams. 1966. A general theory of classificatory sorting strategies. I. Hierarchial systems. Comp. J. 9:373-380.

18. Lechevalier, M. P., and H. A. Lechevalier. 1970. Chemical composition as a criterion in the classification of aerobic actinomycetes. Int. J. Syst. Bacteriol. 20:435-444.

19. Marmur, J. 1961. A procedure for the isolation of deoxyribonucleic acid from microorganisms. J. Mol. Biol. 3:208-218.

20. Marmur, J., and P. Doty. 1962. Determination of the base composition of deoxyribonucleic acid from its thermal denaturation temperature. J. Mol. Biol. 5:109-118.

21. Minnikin, D. E., L. Alshamaony, and M. Goodfellow. 1975. Differentiation of Mycobacterium, Nocardia and related taxa by thin-layer chromatographic analysis of whole-organism methanolysates. J. Gen. Microbiol. 88:200-204.

22. Mordarska, H., S. Cebrat, B. Blach, and M. Goodfellow. 1978. Differentiation of nocardioform actinomycetes by lysozyme sensitivity. J. Gen. Microbiol. 109:381-384.

23. Mordarski, M., M. Goodfellow, J. Kaszen, A. Tkacz, G. Pulverer, and K. P. Schaal. 1980. Deoxyribonucleic acid reassociation in the classification of the genus Rhodococcus Zopf 1891 (Approved Lists, 1980) Int. J. Syst. Bacteriol. 30:521-527.

24. Mordarski, M., M. Goodfellow, K. Szyba, G. Pulverer, and A. Tkacz. 1977. Classification of the 'rhodochrous' complex and allied taxa based upon deoxyribonucleic acid reassociation. Int. J. Syst. Bacteriol. 27:31-38.

25. Mordarski, M., K. Szyba, G. Pulverer, and M. Goodfellow. 1976. Deoxyribonucleic acid reassociation in the classification of the 'rhodochrous' complex and allied taxa. J. Gen. Microbiol. 94:235-245.

26. Nesterenko, G. A., T. M. Nogina, S. A. Kasumova, E. J. Kvasnikov, and S. G. Batrakov. 1982. Rhodococcus luteus nom nov. and Rhodococcus maris nom. nov. Int. J. Syst. Bacteriol. 32:114.

27. Richter, G. 1977. Routine use of thin-layer chromatography for cell wall analysis of aerobic actinomycetes, including two strains from sediments of the North Sea. Veroeff. Inst. Meeresforsch. Bremerhaven 16:125-138.

28. Rowthbotham, T. J., and T. Cross. 1977. Rhodococcus coprophilus sp. nov.: an aerobic nocardioform actinomycete belonging to the 'rhodochrous' complex. J. Gen. Microbiol. 100:123-138.

29. Sierra, G. 1957. A simple method for the detection of lipolytic activity of microorganisms and some observations on the influence of the contact between cells and fatty substrates. Antonie van Leeuwenhoek J. Microbiol. Serol. 23:15-22.

30. Skerman, V. B. D., V. McGowan, and P. H. A. Sneath (ed.) 1980. Approved lists of bacterial names. Int. J. Syst. Bacteriol. 30:225-420.

31. Steinhausen, D., and K. Langer. 1977. Clusteranalyse. Einführung in Methoden und Verfahren der automatischen Klassifikation. Walter de Gruyter, Berlin.

32. Tansey, C. M. T. 1971. Agar-diffusion assay of cellulolytic ability of thermophilic fungi. Arch. Microbiol. 77:1-11.

33. Tsukamura, M. 1971. Proposal of a new genus, Gordona, for slightly acid-fast organisms occurring in sputa of patients with pulmonary disease and in soil. J. Gen. Microbiol. 68:15-26.

34. Weyland, H. 1969. Actinomycetes in North Sea and Atlantic Ocean sediments. Nature (London) 223:858.

35. Weyland, H. 1981. Distribution of actinomycetes on the sea floor. Zentralbl. Bakteriol. Parasitenkd. Infektionskr. Hyg. Abt. 1 Suppl. 11:185-193.

36. Weyland, H. 1981. Characteristics of actinomycetes isolated from marine sediments. Zentralbl. Bakteriol. Parasitenkd. Infektionskr. Hyg. Abt. 1 Suppl. 11:309-314.

37. Weyland, H., H.-J. Rüger, and H. Schwarz. 1970. Zur Isolierung und Identifizierung mariner Bakterien. Veroeff. Inst. Meeresforsch. Bremerhaven 12:269-296.

38. Williams, S. T., and T. Cross. 1971. Actinomycetes, p. 295-334 In C. Booth (ed.), Methods in microbiology, vol. 4. Academic Press., Inc., London. 